\title{
Association between HLA-B alleles and nevirapine-induced allergies among Indonesian HIV patients
}

\author{
Angela Satiti Retno Pudjiati ${ }^{1}$, Dyah Ayu Mira Oktarina ${ }^{1}$, Hardyanto Soebono ${ }^{1}$, Saihas \\ Sauda $^{2}$, Dewi Kartikawati Paramita ${ }^{2}$, Iwan Dwiprahasto ${ }^{3}$, Zubairi Djoerban ${ }^{4}$ \\ 'Department of Dermatology and Venerology, ${ }^{2}$ Laboratory of Molecular Biology, \\ ${ }^{3}$ Department of Pharmacology and Therapy, Faculty of Medicine, Universitas Gadjah \\ Mada, Yogyakarta, ${ }^{4}$ Department of Internal Medicine Faculty of Medicine, University of \\ Indonesia, Jakarta, Indonesia
}

DOI: http://dx.doi.org/10.19106/JMedSci004804201604

\section{ABSTRACT}

This study aimed to investigate the association between human leukocyte antigen-B (HLA-B) alleles and nevirapine allergy in HIV patients in Indonesia. A case control study was conducted involving 147 HIV patients comprising of 50 patients with and 97 patients without nevirapine allergy as control. The HLA-B allele typing was conducted by using polymerase chain reaction-sequence specific oligonucleotide probes (PCR-SSOP), followed by sequencing. Bivariate analysis using Chi-square $\left(\mathrm{X}^{2}\right)$ test and multivariate logistic regression with significance level at $p<0.05$ were applied to analysis the data. Among 147 subjects, 34 with HLA-B alleles were identified. Bivariable analysis showed that HLA-B*58 allele was the most significant risk factor for the nevirapine allergy (OR $=3.67 ; 95 \% \mathrm{Cl}: 1.79$ to 7.54$)$, while HLA-B*35 allele was a protective factor (OR = $0.18 ; 95 \% \mathrm{Cl}: 0.08$ to 0.42 ). Multivariate logistic regression analysis showed that young men and HLA-B $* 58$ allele were the significant risk factors of nevirapine allergy (OR: 4.63; $95 \% \mathrm{Cl}: 2.02$ to 10.61 ), while older women with the HLA-B*35 was able to reduce the risk of nevirapine allergy approximately $81 \%$ (OR: $0.19 ; 95 \% \mathrm{Cl}: 0.08$ to 0.49 ). In conclusion, young male with the HLA-B*58 allele are the high risk factor for nevirapine allergy in Indonesian HIV patients.

\section{ABSTRAK}

Penelitian ini bertujun untuk mengkaji hubungan antara alel human leukocyte antigen-B (HLA-B) dengan kejadian alergi karena nevirapine pada pasien HIV Indonesia. Penelitian dengan rancangan kasus kontrol melibatkan 147 pasien HIV terdiri dari 50 pasien dengan alergi niverapin dan 97 pasien tidak alergi sebagai kontrol. Tipe alel HLA-B dilakukan dengan metode polymerase chain reaction-sequence specific oligonucleotide probes (PCR-SSOP) dilanjutkan dengan skuensing. Analisis bivariate dengan uji Chi-square $\left(X^{2}\right)$ dan regresi logistik multivariat dengan tingkat signifikan $p<0.05$ digunakan untuk menganalisis data. Diantara 147 subjek, 34 subjek teridentifikasi membawa alel HLA-B. Hasil analisis bivariat menunjukkan bahwa HLA-B ${ }^{*} 58$ merupakan factor risiko nyata terjadinya alergi nevirapin $(\mathrm{OR}=3,67 ; 95 \% \mathrm{Cl}: 1,79$ to 7,54$)$, sedangkan alel HLA-B * 35 merupakan faktor protektif $(\mathrm{OR}=0,18 ; 95 \% \mathrm{Cl}: 0,08$ to 0,42$)$. Analisis regresi logistik multivariat menunjukkan lelaki muda dan alel HLA-B ${ }^{*} 58$ faktor risiko nyata terjadinya 
alergi nevirapin (OR: 4,63; $95 \% \mathrm{Cl}: 2,02$ to 10,61 ), sedangkan wanita usia lanjut dengan HLA-B * 35 dapat menurunkan risiko alergi niveripin sekitar $81 \%$ (OR: 0,19; $95 \% \mathrm{Cl}$ : $0,08-0,49)$. Dapat disimpulkan, lelaki muda dengan alel HLA-B ${ }^{*} 58$ mempunyai risiko tinggi menderita alergi nevirapine pada pasien HIV Indonesia.

Key words: HIV - nevirapine - allergy - immunogenetics - HLA-B*58

\section{INTRODUCTION}

The incidence of adverse drug reactions in patients with human immunodeficiency virus (HIV) infection has been widely reported. Allergic drug reactions in HIV patients is 100 times higher than the general population and $3-20 \%$ of them are caused by antiretroviral (ARV) drugs. ${ }^{1}$ Among antiretroviral which most commonly cause allergic reactions are nevirapine (NVP), delavirdine, efavirenz, abacavir and amprenavir. ${ }^{2}$ Nevirapine, a nonnucleoside reverse transcriptase inhibitor (NNRTI) with high efficacy, is the first-line drugs and the drug of choice for pregnant women due to it effectively prevents infection of the fetus. It has been used extensively in countries with limited resources because of the relatively cheap price. However, NVP can cause hypersensitivity reactions, including liver toxicity in about $4.9 \%$ of cases $^{3}$, systemic reactions and skin reactions in as many as 32$48 \%$ cases $^{4,5}$ or severe adverse effects on the skin as Stevens-Johnson Syndrome (SJS) or toxic epidermal necrolysis (TEN) which estimated to occur in $0.3 \%$ cases. $^{6}$

Nevirapine with the trade name Neviral ${ }^{\circledR}$ began to be used in Indonesia as a part of combination therapy for HIV infection since 2004. Data of NVP allergy among human immunodeficiency virus infection/ acquired immune deficiency syndrome (HIV/ AIDS) patients in Indonesia has never been reported yet. A retrospective study conducted by Pudjiati in 2011 showed that of 182 cases of HIV/AIDS treated patients in Dr. Sardjito General Hospital Yogyakarta, 11\% experienced exanthema and more than $90 \%$ of them received NVP treatment. ${ }^{7}$

Differences in HLA type in HIV infected patients have been implicated in the variation of therapeutic response and toxicities of the ARV drugs. The hypothesis that ethnic differences play an important role in patient response to ARV drugs is supported by reports suggesting that patients from different ethnic groups showed different clinical and pharmacokinetics response of ARV drugs significantly. ${ }^{8}$ Previous studies concerning the role of genetic factors in the occurrence of NVP allergy was very limited and the results widely varied. Some studies indicated an association between HLA class I and class II and the development of exanthema due to NVP in different populations. ${ }^{9-12}$ A study in French reported a significant association between the HLA-DRB $1 * 01$ with the development of the exanthema patients treated with 2 NNRTI, while the HLA-DRB*0101 associated with liver-associated side-effects of the NVP. ${ }^{13}$ In Australia, HLA-DRB1*0101 was associated with allergic reactions of NVP. ${ }^{9}$ The HLA-Cw8 and HLA-B14 alleles in Sardinia, Italy, ${ }^{10}$ the HLA-Cw*08 allele in Japan, ${ }^{11}$ the HLA-Cw*04 and HLA-B*3505 alleles in Thailand, ${ }^{14}$ the HLA-B35 allele in India, ${ }^{15}$ the HLA-Cw*04 allele in China, ${ }^{16}$ were associated with side effects of NVP. A toxicogenomics of nevirapine-associated adverse events among populations reported 
that cutaneous adverse events were associated HLA-Cw*04 and HLA-B*35 alleles among Asian population, HLA-Cw*04 allele among Africans population and HLA-DRB*01 allele among European population. ${ }^{17}$

The high frequency of HLA-B among Indonesian populations has been reported in the previous study. ${ }^{18}$ This study was performed to investigate the neveripine-induced allergies in association with HLA-B alleles among Indonesian HIV patients.

\section{MATERIALS AND METHODS}

\section{Subjects}

The study was designed by using a casecontrol study involving 152 HIV patients who registered at the HIV/AIDS Clinic of Dr. Sardjito General Hospital, Panti Rapih Hospital, Bethesda Hospital, Panembahan Senopati Hospital, Yogyakarta, Indonesia. Patients who had experienced NVP allergy clinically manifested on the skin and/or abnormalities in AST and/or ALT were allocated into Case group; whereas patients who had consumed ARV within 6 months of therapy but tolerance or did not suffer from NVP allergy were allocated into Control group. The protocol of this study has been approved by the Health Research Ethics Committee of the Faculty of Medicine, Universitas Gadjah Mada, Yogyakarta.

\section{HLA-B typing}

Ten millimeter of peripheral blood sample were taken by venipuncture from all subjects both from the Case and the Control groups. The peripheral blood mononuclear cell (PBMC) were separated and the DNA was isolated. Typing of HLA alleles was according to Itoh et al. ${ }^{19}$ using PCR-SSOP-Lumnex method, followed by sequencing.

\section{Statistical analysis}

Data were analyzed using bivariate analysis with Chi-square $\left(\mathrm{X}^{2}\right)$ test and using multivariate logistic regression with significance level at $\mathrm{p}<0.05$. Association between HLA and other risk factors with NVP allergy was expressed using Odds Ratio (OR) and $95 \%$ confident intervals.

\section{RESULTS}

\section{Characteristic of subjects}

A number of 152 subjects of HIV patient were included in this study, of whom 52 subjects suffering NVP allergy and 100 tolerant subjects with no NVP allergy. TABLE 1 shows the different characteristic of the Case and the Control groups. Higher proportion of male were found in NVP allergy group compared to no NVP allergy group $(\mathrm{OR}=2.17$; $\mathrm{CI}$ : 1.22 to 3.88 ). The median age was younger in the Case group compared to those in the control group $(p<0.05)$. No different in CD4 cell count before ARV therapy, the median of body mass index (BMI) as well as the initial dose NVP were found between cases and controls. Maculopapular eruptions or allergic reaction grade $2^{\text {nd }}$ (according to DAIDS) was the majority clinical manifestation (71.15\%), while SJS were found in $7.69 \%$ of subjects. Hepatotoxicity was found in 31 subjects $(59.62 \%)$ as shown in the elevation of the enzymes; $30.77 \%$ in the first degree, $15.38 \%$ in second degree, while $13.46 \%$ in $3^{\text {rd }}$ and $4^{\text {th }}$ degrees. 
TABLE 1. Characteristics of subjects in the Case and the Control groups.

\begin{tabular}{|c|c|c|c|c|}
\hline Characteristics & $\begin{array}{c}\text { Case } \\
(\mathrm{n}=52)\end{array}$ & $\begin{array}{c}\text { Control } \\
(\mathrm{n}=100)\end{array}$ & $\begin{array}{c}\text { Total } \\
(n=152)\end{array}$ & $\mathrm{p}$ \\
\hline \multicolumn{5}{|l|}{ Gender $[\mathrm{n}(\%)]$} \\
\hline - Male & $40(76.92)$ & $54(54.00)$ & $94(61.84)$ & \multirow{2}{*}{0.01} \\
\hline - Female & $12(23.10)$ & $46(46.00)$ & $58(38.16)$ & \\
\hline \multicolumn{5}{|l|}{ Age $[\mathrm{n}(\%)]$} \\
\hline - $\quad<33$ years old & $32(61.54)$ & $39(39.00)$ & $71(46.71)$ & \multirow{2}{*}{0.01} \\
\hline - $\quad \geq 33$ years old & $20(38.46)$ & $61(61.00)$ & $81(53.29)$ & \\
\hline \multicolumn{5}{|l|}{ CD4 count before NVP } \\
\hline - $\quad \geq 250$ cells $/ \mathrm{mm}^{3}$ & $14(26.92)$ & $19(19.00)$ & $33(21.71)$ & \multirow{2}{*}{0.26} \\
\hline - $\quad<250$ cells $/ \mathrm{mm}^{3}$ & $38(38.46)$ & $81(81.00)$ & $119978.29)$ & \\
\hline \multicolumn{5}{|l|}{ BMI base line } \\
\hline - $\quad<18$ & $21(40.38)$ & $44(44.00)$ & $65(42.76)$ & \multirow{2}{*}{0.67} \\
\hline - $\quad \geq 18$ & $31(59.62)$ & $56(56.00)$ & $87(57.24)$ & \\
\hline \multicolumn{5}{|l|}{ Initial dose of NVP } \\
\hline - $\quad 2 \times 200 \mathrm{mg} / \mathrm{day}$ & $9(17.31)$ & $8(8.00)$ & $17(11.18)$ & \multirow{2}{*}{0.08} \\
\hline - $\quad 1 \times 200 \mathrm{mg} /$ day & $43(82.69)$ & $92(92.00)$ & $135(88.82)$ & \\
\hline
\end{tabular}

\section{HLA-B alleles}

Of the 52 subjects in the NVP allergy group and 100 samples of the control group, only 50 and 97 samples respectively could be analyzed because the sequencing results on 5 samples showed alkaline chain length of about $150 \mathrm{bp}$ which should be 482 bp in HLA-B gene. TABLE 2 shows 34 types of single allele of HLA-B as a result of a combination of bases 211-240. The results of the bivariate analysis of 34 types of HLA-B alleles, 17 types of HLA-B alleles were significantly associated with NVP allergy $(\mathrm{p}<0.05)$ with the highest OR in HLA-B*58 (OR $=3.67 ; 95 \%$ CI: 1.78 to 7.53$)$, while HLA-B*35 showed a protective allele for NVP allergy $(\mathrm{OR}=0.18$; $93 \%$ CI: 0.08 to 0.42 ). 
TABLE 2. Association of HLA-B alleles and NVP allergy

\begin{tabular}{|c|c|c|c|c|}
\hline Allele & $\begin{array}{c}\text { NVP allergy } \\
{[\mathrm{n}(\%)]}\end{array}$ & $\begin{array}{l}\text { Control } \\
{[\mathrm{n}(\%)]}\end{array}$ & $\mathrm{p}$ & OR $(95 \% \mathrm{CI})$ \\
\hline $\mathrm{B} * 07$ & $21(42.00)$ & $20(20.62)$ & 0.01 & $2.79(1.32-5.88)$ \\
\hline $\mathrm{B} * 08$ & $21(42.00)$ & $18(18.56)$ & 0.00 & $3.18(1.49-6.80)$ \\
\hline $\mathrm{B} * 13$ & $17(34.00)$ & $13(13.40)$ & 0.00 & $3.33(1.46-7.61)$ \\
\hline $\mathrm{B} * 14$ & $4(8.00)$ & $7(7.22)$ & 1.00 & $1.12(0.31-4.02)$ \\
\hline $\mathrm{B} * 15$ & $31(62.00)$ & $35(36.08)$ & 0.00 & $2.89(1.43-5.85)$ \\
\hline $\mathrm{B} * 18$ & $23(46.00)$ & $30(30.93)$ & 0.07 & $1.90(0.94-3.84)$ \\
\hline$B * 27$ & $15(30.00)$ & $24(24.74)$ & 0.49 & $1.30(0.61-2.79)$ \\
\hline $\mathrm{B} * 35$ & $9(18.00)$ & $53(54.64)$ & 0.00 & $0.18(0.08-0.47)$ \\
\hline$B * 37$ & $28(56.00)$ & $36(37.11)$ & 0.03 & $2.16(1.08-4.32)$ \\
\hline $\mathrm{B} * 38$ & $21(42.00)$ & $19(19.59)$ & 0.00 & $2.19(1.52-6.83)$ \\
\hline$B * 39$ & $23(46.00)$ & $20(20.62)$ & 0.00 & $3.28(1.56-6.89)$ \\
\hline$B * 40$ & $32(64.00)$ & $35(36.08)$ & 0.00 & $3.15(1.55-6.41)$ \\
\hline$B * 41$ & $1(2.00)$ & $4(4.12)$ & 0.85 & $0.47(0.05-4.35)$ \\
\hline$B * 42$ & $5(10.00)$ & $6(6.19)$ & 0.67 & $1.69(0.49-5.82)$ \\
\hline$B * 44$ & $33(66.00)$ & $35(36.08)$ & 0.00 & $3.44(1.68-7.04)$ \\
\hline$B * 45$ & $1(2.00)$ & $5(5.15)$ & 0.63 & $0.38(0.04-3.31)$ \\
\hline $\mathrm{B} * 46$ & $32(64.00)$ & $38(39.18)$ & 0.00 & $2.76(1.36-5.60)$ \\
\hline$B * 47$ & $1(2.00)$ & $4(4.12)$ & 0.85 & $0.47(0.05-4.36)$ \\
\hline$B * 48$ & $5(10.00)$ & $6(6.19)$ & 0.62 & $1.69(0.49-5.82)$ \\
\hline$B * 49$ & $22(44.00)$ & $23(23.71)$ & 0.02 & $2.53(1.22-5.24)$ \\
\hline $\mathrm{B} * 51$ & $33(66.00)$ & $43(44.32)$ & 0.01 & $2.44(1.20-4.95)$ \\
\hline $\mathrm{B} * 52$ & $32(64.00)$ & $37(38.14)$ & 0.00 & $2.88(1.42-5.85)$ \\
\hline$B * 53$ & $20(40.00)$ & $24(24.74)$ & 0.06 & $2.03(0.98-4.21)$ \\
\hline $\mathrm{B} * 55$ & $15(30.00)$ & $19(19.59)$ & 0.16 & $1.76(0.80-3.86)$ \\
\hline $\mathrm{B} * 56$ & $31(62.00)$ & $32(32.99)$ & 0.00 & $3.31(1.63-6.76)$ \\
\hline$B * 57$ & $16(32.00)$ & $28(28.87)$ & 0.69 & $1.16(0.55-2.43)$ \\
\hline $\mathrm{B} * 58$ & $28(56.00)$ & $25(25.77)$ & 0.00 & $3.67(1.78-7.53)$ \\
\hline$B * 59$ & $4(8.00)$ & $6(6.19)$ & 0.95 & $1.32(0.35-4.91)$ \\
\hline$B * 67$ & $4(8.00)$ & $6(6.19)$ & 0.95 & $1.32(0.35-4.91)$ \\
\hline $\mathrm{B} * 73$ & $4(8.00)$ & $6(6.19)$ & 0,95 & $1.32(0.35-4.91)$ \\
\hline $\mathrm{B} * 78$ & $17(34.00)$ & $13(13.40)$ & 0.00 & $3.33(1.46-7.61)$ \\
\hline $\mathrm{B} * 81$ & $4(8.00)$ & $6(6.19)$ & 0.95 & $1.32(0.35-4.91)$ \\
\hline $\mathrm{B} * 82$ & $4(8.00)$ & $6(6.19)$ & 0.95 & $1.32(0.35-4.91)$ \\
\hline$B * 83$ & $4(8.00)$ & $6(6.19)$ & 0.95 & $1.32(0.35-4.91)$ \\
\hline
\end{tabular}

Multivariate analysis of all variables (characteristic subjects and HLA types) was then performed to assess which variables which were most substantial as predictors for the NVP allergy in HIV patients. The 2-digit single HLA alleles that shown the highest risk for NVP allergy was HLA-B*58 (OR: 4.63; 95\% CI: 2.02 to 10.61$)$, and that shown a high protection was HLA-B*35 (OR: 0.19; 95\% CI: 0.08 to 0.49 ). Male and younger individual were risk factors for the occurrence of NVP allergies (TABLE 3). 
TABLE 3. Multivariate analysis of subject characteristics and single allele HLA-B sequences 2 digits for NVP allergy

\begin{tabular}{|c|c|c|}
\hline Variables & $\begin{array}{c}\text { OR }(95 \% \mathrm{CI}) \\
\text { unadjusted }\end{array}$ & $\begin{array}{c}\text { OR }(95 \% \mathrm{CI}) \\
\text { adjusted }\end{array}$ \\
\hline Gender & \multirow{3}{*}{$2.84(1.33-6.04)$} & \multirow{3}{*}{$2.63(1.23-5.63)$} \\
\hline $\begin{array}{l}\text { Male } \\
\text { Female }\end{array}$ & & \\
\hline Age & & \\
\hline $\begin{array}{l}<33 \text { years old } \\
\geq 33 \text { years old }\end{array}$ & $2.84(1.33-6.04)$ & $2.63(1.23-5.63)$ \\
\hline HLA-B*07 & $2.79(1.32-5.88)$ & $2.74(1.19-6.32)$ \\
\hline HLA-B*08 & $3.18(1.49-6.80)$ & $3.27(1.39-7.71)$ \\
\hline HLA-B*15 & $2.89(1.43-5.85)$ & $3.20(1.47-6.96)$ \\
\hline HLA-B*18 & $1.90(0.94-3.84)$ & $2.10(0.96-4.58)$ \\
\hline HLA-B*35 & $0.18(0.08-0.42)$ & $0.19(0.08-0.49)$ \\
\hline HLA-B*37 & $2.16(1.08-4.32)$ & $2.41(1.11-5,23)$ \\
\hline HLA-B*38 & $2.19(1.52-6.83)$ & $2.93(1.26-6.84)$ \\
\hline HLA-B*39 & $3.28(1.56-6.89)$ & $3.21(1.40-7.35)$ \\
\hline HLA-B*40 & $3.15(1.55-6.41)$ & $3.20(1.47-6.96)$ \\
\hline HLA-B*44 & $3.44(1.68-7.04)$ & $3.79(1.72-8.34)$ \\
\hline HLA-B*46 & $2.76(1.36-5.60)$ & $2.98(1.37-6.50)$ \\
\hline HLA-B*49 & $2.53(1.22-5.24)$ & $2.36(1.04-5.36)$ \\
\hline HLA-B*51 & $2.44(1.20-4.95)$ & $2.96(1.35-6.49)$ \\
\hline HLA-B $* 52:$ & $2.88(1.42-5.85)$ & $3.58(1.63-7.89)$ \\
\hline HLA-B*56 & $3.35(1.63-6.76)$ & $3.57(1.64-7.79)$ \\
\hline HLA-B*58 & $3.67(1.78-7.53)$ & $4.63(2.02-10.61)$ \\
\hline HLA-B*78 & $3.33(1.46-7.61)$ & $4.00(1.50-10.67)$ \\
\hline
\end{tabular}

\section{DISCUSSION}

This study found that men were more likely to have NVP allergy compared to women (78\%: 22\%). However, if severity of NVP allergy was taken into account women were more severe than men $(18.18 \%$ : $17.95 \%)$. This is in contrast to previous studies that NVP allergy was more common in faemale. ${ }^{15,20-24}$ According to Soldin et al. ${ }^{25}$ there are differences in pharmacokinetics, drug effects and toxicities of drugs between men and women, in addition to many influential factors, such as socio-cultural differences, behavioral factors, body size, body composition, genetic, biochemical and hormonal factors. Another explanation that men had higher risk to women was the BMI $(<18)$ in men seven times lower than women (9.2\%: 1.3\%); although in this study low BMI statistically was not a significant risk factor of NVP allergy.

In this study, younger age, under 33 years of age was at risk for the occurrence of NVP allergy. This is contrast with the study of Ananworanich et al. ${ }^{23}$ which showing no relationship between age and the incidence of NVP allergy. Warrington and Silviu-Dan ${ }^{26}$ suggested that the drug allergy commonly 
occurred in young adults and the middle age. Jimmy and Padma ${ }^{27}$ demonstrated that the type of ADR type A was significantly more common in older adults (85.9\%), while ADR type B were more common in adults $(35 \%)$.

Sequencing in the family level (two digit sequences) in 147 subjects (50 cases and 97 controls), identified 34 alleles of HLA-B. The highest frequency of allele in this population was HLA-B*51 (51.70\%). This is consistent with the results reported by Yuliwulandari et $a l .{ }^{18}$ in healthy subjects, that shown the highest frequency of HLA-B (40 alleles); and the mostly frequently of HLA-B*15.02 (11.6\%) and HLA-B*15.13 (11.2\%). A study in Malaysian population found 15 types of allele HLA-A, 29-type allele HLA-B, and 14 types of HLA-DR alleles; with the highest frequency of HLA-A*24 (35\%), HLA-B*15 $(26 \%)$, and HLA-DRB1*15 (28\%). ${ }^{28}$

Bivariate analysis of 34 types of single allele HLA-B sequence of two digits, demonstrated that 17 types of alleles that $B^{*} 07$, $\mathrm{B}^{*} 08, \mathrm{~B}^{*} 13, \mathrm{~B}^{*} 15, \mathrm{~B}^{*} 35, \mathrm{~B}^{*} 37, \mathrm{~B}^{*} 38, \mathrm{~B}^{*} 39$, $B * 40, B^{*} 44, B^{*} 46, B^{*} 49, B^{*} 51, B^{*} 52, B^{*} 56$, $B^{*} 58$ and $B^{*} 78$ were significantly associated with NVP allergy, with the highest risk was in HLA-B $* 58$ alleles $(\mathrm{OR}=3.67 ; 95 \% \mathrm{CI}: 1.78$ to 7.53 ), while the allele HLA-B*35 alleles were significantly as protection alleles (OR $=0.18 ; 95 \%$ CI: 0.08 to 0.42 ). This result was different to the previous studies in Sardinia Italy that HLA-B*14, ${ }^{10}$ and in Japan that HLA-B*3505, ${ }^{11}$ were the high risk factors of NVP allergy. ${ }^{12}$ Another studies in India and in China consistently found the HLA-B*35 was the risk factor of NVP allergy. ${ }^{15,16}$

HLA alleles responsible for the risk factors for NVP allergy in this study were different from previous studies. In addition to the ethnic differences, the other possible differences was due to the focus of the study in which we included allergic manifestation both the skin and the liver. The study of Likanonsakul et al. ${ }^{14}$ only observed on skin manifestations which they suggested that the degree of linkage disequilibrium between alleles HLA-B, HLA-C or other HLA alleles and individuals from other HLA loci and / or other genes occurs between ethnic groups. As demonstrated in several studies that allele HLA-Cw*04 was associated with the progression toward AIDS in the Caucasian but it showed a protective effect on African American. ${ }^{29}$ Another study conducted by Ananworanich et al.$^{23}$ found that the exanthema due to NVP allergy 2.8 times more prevalent in Thais than in white skin population. Study on Chinese and Thai populations showed that the SJS/TEN for carbamazepine were associated with HLA-B*1502, but not in Caucasian and Japanese populations as $\mathrm{B}^{*} 1502$ allele is extremely rare in the Caucasian and Japanese population. ${ }^{30-33}$

The finding of various HLA-B alleles play role as risk factors in this study may also be due to the fact that these alleles were found in the Mongoloid race which comprised of Indonesian ${ }^{18}$, in Malaysian, ${ }^{28}$ and in north of Chinese. ${ }^{34}$ The finding of HLA-B*35 type allele as a protective factor for NVP allergy in this study gives an opportunity to further study to the role of $\mathrm{CD}_{8}$ T cells in type IV drug allergy, in contrasts to the studies in other countries showing the HLA-B*35 as a strong risk factor for nevirapine allergy $(\mathrm{OR}=18,34) \cdot{ }^{17}$ Further studies are required to perform to confirm the role of these alleles in restriction to $\mathrm{CD}_{8}+$ cells related to NVP allergy.

\section{CONCLUSION}

This result shows that men, younger age and HLA-B*58 allele are the significant risk factors of NVP allergy (OR: 4.634; 95\% CI: 2.024 to 10.611 ), while women older age with 
the HLA-B*35 is able to reduce the risk of NVP allergy (OR: $0.191 ; 95 \%$ CI: 0.075 to 0.487).

\section{ACKNOWLEDGEMENTS}

The authors would like to thank Director of Dr. Sardjito General Hospital, Panti Rapih Hospital, Bethesda Hospital, Panembahan Senopati Hospital, Yogyakarta, Indonesia for their permission to perform this study. We would like to thank all subjects who participated in this study.

\section{REFERENCES}

1. Severino Gand Zompo MD. Adverse drug reactions: role of pharmacogenomics. Pharmacol Res 2004; 49: 36373. https://doi.org/10.1016/j.phrs.2003. 05.003

2. Carr A \& Cooper DA. Adverse effects of antiretroviral therapy. Lancet 2000; 356:1423-30. https://doi.org/10.1016/S0140-6736(00) 02854-3

3. Hülsmeyer M, Fiorillo MT, Bettosini F, Sorrentino R, Saenger W, Ziegler A, et al., Dual HLA-B27 subtype-dependent conformation of a self-peptide. J Exp Med 2004; (2): 271-81. https://doi.org/10.1084/jem.20031690

4. Mesquita F, Winarso I, Atmosukarto II, Eka B, Nevendorff L, Rahmah A, et al. Public health the leading force of the Indonesian respons to HIV/AIDS crisis among people who inject drugs. Harm Reduct J 2007; 4:9. https://doi.org/10.1186/1477-7517-4-9

5. Warren KJ, Boxwell DE, Kim NY, Drolet BA. Nevirapine-associated StevensJohnson syndrome. Lancet 1998; 351:567. https://doi.org/10.1016/S01406736(98)24008-6
6. Pollard VW \& Malim MH. The hiv-1 rev protein. Ann Rev Microbiol 1998; 52: 491-532 . https://doi.org/10.1146/annurev. micro.52.1.491

7. Pudjiati SR. Mucocutanous manifestations in HIV-infected Indonesian patients. Neth J DerVen 2011; (Suppl).

8. Cressey TR \& Lallement M. Pharmacogenetics of antiretroviral drugs for the treatment of HIV-infected patients: An update. Infect Genet Evol 2007; 7:333-42. h t tp s: / / d o i.org / $10.1016 /$ j. meegid.2006.08.004

9. Martin AM, Nolan D, James I, Cameron P, Keller J, Moore C, et al. Predisposition to nevirapine hypersensitivity associated with HLA-DRB $1 * 0101$ and abrogated by low CD4 T-cell counts. AIDS 2005; 19(1):97-9. https://doi.org/10.1097/00002030200501030-00014

10. Littera R, Carcassi C, Masala A, Piano P, Serra P, Ortu F, et al. HLA-dependent hypersensitivity to neverapine in Sardinian HIV patients. AIDS 2006; 20(12):1621-6. https://doi.org/10.1097/01.aids. 0000238408.82947.09

11. Gatanaga H, Yazaki H, Tanuma J, Honda M, Genka I, Teruya K, et al. HLA-Cw8 primarily associated with hypersensitivity tonevirapine. AIDS 2007; 21:264-5. https://doi.org/10.1097/QAD.0b013e 32801199d9

12. Chantarangsu S, Mushiroda T, Mahasirimongkol S, Kiertiburanakul S, Sungkanuparph S, Manosuthi W, et al. HLA-B*3505 allele is a strong predictorfor nevirapine-induced skin adverse drug reactions in HIV-infected Thai patients. Pharmacogenet Genomics 2009; 9:139-46. h t t p s : / / d o i.org / 10.1097 / FPC.0b013e32831d0faf 
13. Vitezica ZG, Milpied B, Lonjou C, Borot $\mathrm{N}$, Ledger $\mathrm{TN}$, Lefebvre A, et al. HLA$\mathrm{DRB} 1 * 01$ associated with cutaneous hypersensitivity induced by nevirapine and efavirenz. AIDS 2008; 22(4):540-1. h t t p s : / / d o i.org / 10.1097 / QAD.0b013e3282f37812

14. Likanonsakul S, Rattanatham T, Feangvad S, Uttayamakul S, Prasithsirikul W, Tunthanathip P, et al. HLA-Cw*04 allele associated with nevirapine-induced rash in HIV-infected Thai patients. AIDS Res Ther 2009; 6:22. doi: 10.1186/1742-6405-6-22 https://doi.org/10.1186/1742-6405-6-22

15. Umapathy S, Pawar A, Bajpai S, Pazare AR, Ghosh K. HLA involvement in nevirapine-induced dermatological reaction in antiretroviral-treated HIV-1 patients. J Pharmacol Pharmacother 2011; 2(2): 114-5. https://doi.org/10.4103/0976500X.81905

16. Gao S, Gui X, Liang K, Liu Z, Hu J, Dong B. HLA-dependent hypersensitivity reaction to nevirapineinChineseHanHIV-infectedpatients. AIDS Res Human Retrovir 2012; 28(6):540-3. https://doi.org/10.1089/aid.2011.0107

17. Yuan J, Guo S, Hall D, Cammett AM, Jayadev S, Distel M, et al. Toxicogenomics of nevirapine-associated cutaneous and hepatic adverse events among populations of African, Asian, and European descent. AIDS 2011; 25(10): 1271-80. h t t p s: / / d o i.org / 10.1097 / QAD.0b013e32834779df

18. Yuliwulandari R, Kashiwase K, Nakajima $\mathrm{H}$, Uddin J, Susmiarsih TP, Sofro AS, et al. Polymorphisms of HLA genes in Western Javanese (Indonesia): close affinities to Southeast Asian populations. Tissue Antigens 2009; 73(1):46-53. https://doi.org/10.1111/j.13990039.2008.01178.x
19. Itoh Y, Mizuki N, Shimada T, Azuma F, Itakura $\mathrm{M}$, Kashiwase $\mathrm{K}$, et al. Highthroughput DNA typing of HLA-A, -B, $-\mathrm{C}$, and -DRB1 loci by a PCR-SSOPLuminex method in the Japanese population. Immunogenetics 2005; 57(10):717-29. https://doi.org/10.1007/s00251-0050048-3

20. Antinori A, Baldini F, Girardi E, Cingolani A, Zaccarelli M, Di Giambenedetto S, et al. Female sex and the use of anti-allergic agents increase the risk of developing cutaneous exantema associated with nevirapine therapy. AIDS 2001; 15:1579-81. https://doi.org/10.1097/00002030200108170-00018

21. Bersoff-Matcha SJ, Miller WC, Aberg JA, van Der Hosrst C, Hamrick HJ Jr, Powderly $\mathrm{WG}$, et al. Sex differences in nevirapine exantema. Clin Infect Dis 2001; 32:124-9. https://doi.org/10.1086/317536

22. van Leth F, Andrews S, Grinsztejn B. The effect of baseline CD4 cell count and HIV1 viral load on the efficacy and safety of nevirapine or efavirenz-based first-line HAART. AIDS 2005; 19(5): 463-71. h t t p s : / / d oi .org / 10.1097 / 01 . aids.0000162334.12815.5b

23. Ananworanich J, Moor Z, Siangphoe U, Chan J, Cardiello P, Duncombe C, et al. Incidence and risk factors for exantema in Thai patients randomized to regimenswithnevirapine, efavirenz or both drugs. AIDS 2005; 19(2):185-92 https://doi.org/10.1097/00002030200501280-00011

24. Kappelhoff BS, van Leth F, Robinson PA, mac Gregor TR, Baraldi E, Montella F, et al. Are adverse events of nevirapine and efavirenzrelated to plasma concentrations? Antivir Ther 2005; 10(4):489-98. 
25. Soldin OP, Chung SH, Mattison DR. Sex difference in drug disposition. J Biomed Biotechnol 2011; DOI:10.1155/2011/187103 https://doi.org/10.1155/2011/187103

26. Warrington $\mathrm{R} \&$ Silviu-Dan $\mathrm{F}$. Drug allergy. Allergy, Asthma Clin Immunol 2011， 7(Suppl 1):S10. https://doi.org/10.1186/1710-1492-7S1-S10

27. Jimmy J \& Padma GMR. Pattern of adverse drug reactions notified by spontaneous reporting in an Indian tertiary care teaching hospital. Pharmacol Res 2006; 54:226-33. https://doi.org/10.1016/j.phrs.2006. 05.003

28. Dhaliwal JS, Shahnaz M, Too CL, Azrena A, Maiselamah L, Lee YY, et al. HLA-A, -B and $-\mathrm{DR}$ allele and haplotype frequencies in Malays. Asian Pac J Allergy Immunol 2007; 25:47-51.

29. Carrington M, Nelson GW, Martin MP, Kissner T, Vlahov D, Goedert JJ, et al. HLA and HIV1: heterozygote advantage and $\mathrm{B} * 35-\mathrm{CW}^{*} 04$ disadvantage. Science 1999; 283:1748-52. https://doi.org/10.1126/science. 283.5408.1748

30. Alfirevic A, Jorgensen AL, Williamson PR, Chadwick DW, Park BK, Pirmohamed M. HLA-B locus in Caucasian patients with carbamazepine hypersensitivity. Pharmacogenomics 2006; 7(6): 813-8. https://doi.org/10.2217/ 14622416.7. 6.813

31. Chung WH, Hung SI, Hong HS, Hsih MS, Yang LC, Ho HC, et al. Medical genetics: a marker for Stevens-Johnson Syndrome. Nature 2004; 428 (6982): 486. https://doi.org/10.1038/428486a

32. Hung SI, Chung WH, Jee SH, Chen WC, Chang YT, Lee WR, et al. Genetic Susceptibuility to carbamazepine-induced cutaneous adverse drug reactions. Pharmacogenet Genomics 2006; 16(4): 297-306. h t tp s: / / d o i.org / 10.1097 / 01 . fpc.0000199500.46842.4a

33. Lonjou C, Thomas L, Borot N, Ledger N, de Toma C, LeLouet $\mathrm{H}$, et al. A marker for StevensJohnson syndrome: ethnicity matters. Pharmacogenomics J 2006; 6(4):265-8. h t t p s: / / d o i.org / 10.1038 / sj.tpj.6500356

34. Zhu B, Yang G, Shen C, Qin H, Liu S, Deng Y, et al. Distributions of HLA-A and $-\mathrm{B}$ alleles and haplotypes in the Yi ethnic minority of Yunnan, China: relationship to other populations. J Zhejiang Univ-Sci B (Biomed \& Biotechnol) 2010; 11(2):127-135 https://doi.org/10.1631/jzus. B0900232 